\title{
Simultaneous Measurement of Thyroxine and Triiodothyronine Peripheral Turnover Kinetics in Man
}

\author{
John T. Nicoloff, James C. Low, Jean H. Dussault, and \\ DeLbert A. Fisher \\ From the Department of Medicine, University of Southern California School \\ of Medicine, University of California at Los Angeles School of Medicine, \\ and the Los Angeles County University of Southern California Medical \\ Center, Los Angeles, California 90033
}

\begin{abstract}
A в S T R A C T Serum triiodothyronine $\left(T_{3}\right)$ kinetics in man have been difficult to define presumably due to the interference of iodoproteins generated during the peripheral metabolism of $\mathrm{T}_{\mathrm{s}}$. The use, in the present study, of an anion-column chromatographic method for separation of serum $T_{3}$ as well as thyroxine $\left(T_{4}\right)$ from these iodoproteins has overcome this technical handicap. Simultaneous measurement of serum ${ }^{125} \mathrm{I}_{-} \mathrm{T}_{\mathbf{s}}$ and ${ }^{121} \mathrm{I}-\mathrm{T}$. kinetics were performed in 31 subjects from the clinical categories of euthyroid, primary hypothyroid, thyrotoxic and posttreatment hypothyroid Graves' disease, factitial thyrotoxic, and idiopathically high and low thyroxinebinding globulin states. The normal mean $T_{8}$ fractional turnover rate $\left(\mathrm{kT}_{\mathbf{3}}\right)$ was 0.68 (half-life $=1.0$ days), increased in toxic Graves' disease patients to 1.10 (halflife $=0.63$ days), and decreased in primary hypothyroid patients to 0.50 (half-life $=1.38$ days). The mean $\mathrm{T}_{2}$ equilibration time averaged $22 \mathrm{hr}$ except in hypothyroid and high thyroxine-binding globulin (TBG) patients where the equilibration period was delayed by $10 \mathrm{hr}$. The mean $T_{3}$ distribution space in normal subjects was 38.4 liters. This was reduced in subjects with high TBG levels (26 liters) and increased in patients with low TBG and in all hyperthyroid states (53-55 liters). The normal serum $T_{s}$ concentration was estimated by radioimmunoassay to be $0.106 \mu \mathrm{g} / 100 \mathrm{ml}$. Combined with the mean $T_{3}$ clearance value of 26.1 liters/day, the calculated $T_{3}$ production rate was $27.6 \mu \mathrm{g} / \mathrm{day}$. The mean $T_{s}$ production rate increased to $201 \mu \mathrm{g} /$ day in
\end{abstract}

Presented in part at the 52nd Annual Meeting of the Endocrine Society, 11 June 1970.

Dr. Low's present address is Walter Reed Army Medical Center, Washington, D. C. and Dr. Dussault's present address is Centre Hospitalier, Universitaire Laval, Quebec, P. Q., Canada.

Received for publication 19 April 1971 and in revised form 7 September 1971. thyrotoxic Graves' disease patients and was reduced to $7.6 \mu \mathrm{g} /$ day in primary hypothyroid subjects. Ts production rate was normal in subjects with altered TBG states. The ratio of $T_{3}$ to $T_{4}$ production rate in normal subjects was 0.31 and was unchanged in patients with altered TBG values. This ratio was increased in all Graves' disease patients with the highest value being 0.81 in the posttreatment hypothyroid Graves' disease group. This apparent preferential production of $T_{3}$ may have been responsible for the retention of rapid turnover kinetics for $T_{3}$ and $T_{4}$ observed in treated Graves' disease patients. The finding that factitial thyrotoxic patients also displayed similar rapid $T_{3}$ and $T_{4}$ turnover kinetics indicates that these alterations are not a unique feature of Graves' disease per se. When comparing the peripheral turnover values for $T_{3}$ and $T_{4}$ in man, it is apparent that alterations in metabolic status and serum TBG concentration influence both hormones in a parallel manner; however, changes in metabolic status seem to have a greater influence on $T_{3}$ kinetics while alterations in TBG concentrations have a greater effect on $T_{\text {s. The }}$ The observations probably relate to the differences in TBG binding affinity and peripheral tissue distribution of these two hormones.

\section{INTRODUCTION}

Since the introduction of radioactive iodine labeled thyroxine $\left(T_{4}\right)^{1}$ as a testing tool in clinical research, numerous studies of $T$, peripheral metabolism have been performed in man (1). By contrast, comparatively few

\footnotetext{
${ }^{1}$ Abbreviations used in this paper: DS, distribution space; $\mathrm{kT}_{3}$, triiodothyronine fractional turnover rate; $\mathrm{kT}_{4}$, thyroxine fractional turnover rate; MCR, metabolic clearance rate; RIA, radioimmunoassay; $T_{3}$ triiodothyronine; $T_{4}$, thyroxine; TBG, thyroxine-binding globulin; $U$, urinary.
} 
investigations have dealt with the metabolism of triiodothyronine $\left(\mathrm{T}_{3}\right)$, and the information available is variable and at times conflicting. Early estimates of the biological half-life of $T_{3}$ in euthyroid human subjects were reported to be greater than 2 days (2), while recently published values have varied between 1.30 and 1.6 days (3-5). This difficulty in accurately assessing $T_{s}$ kinetics probably relates to the generation of circulating iodoproteins appearing during $T_{\mathbf{s}}$ degradation. Surks and Oppenheimer have found that these iodoproteins appear chemically and biologically similar to serum albumin and interfere with the conventional measurements of labeled $T_{s}$ in the serum (6). While comparing the peripheral deiodination rates of labeled $T_{s}$ and $T_{4}$ in man ( 7$)$, we have observed that the rate of $T_{3}$ degradation, measured by assessing the rate of urinary excretion of radioactive label, is more rapid than the values previously cited in the literature. This observation, coupled with the iodoprotein studies of Surks and Oppenheimer (6), stimulated our interest in assessing labeled $T_{3}$ and $T_{4}$ kinetics in normal subjects and in patients with alterations in thyroid status.

\section{METHODS}

The subjects employed in this investigation were from the inpatient and outpatient services of the Los Angeles CountyUniversity of Southern California Medical Center. Subject classification was established by clinical examination and conventional thyroid testing (see Table I). The eight euthyroid control subjects were either normal volunteers or patients with mild nonthyroidal illnesses such as duodenal ulcer or mild exogenous obesity. The six patients with primary hypothyroidism had spontaneous thyroid failure as adults. The thyrotoxic Graves' disease group was comprised of seven subjects all manifesting classic signs and symptoms of hyperthyroidism. Subjects were selected who displayed a variety of serum $T_{4}$ values including patients No. 6 and No. 7 who had normal serum total and free thyroxine determinations. None of the patients had been taking an antithyroid drug (methimazole) for more than $1 \mathrm{wk}$ before the time of the study. The three patients with hypothyroid Graves' disease developed their hypothyroidism as a result of inadvertent overtreatment with methimazole; they had been hypothyroid for a period of 2-3 months before study and had developed gross myxedema. The three patients with factitial thyrotoxicosis had been ingesting thyroid hormone in an effort to control mild exogenous obesity and/or mental depression. Subject 1 in this group had been taking $0.9 \mathrm{mg}$ L-thyroxine daily, while subjects 2 and 3 were each ingesting 9 gr of desiccated thyroid daily. In each instance, these doses of thyroid hormone had been maintained for periods in excess of $1 \mathrm{yr}$. The patients with idiopathically high and low TBG values were clinically euthyroid and in good health.

Pulse $T_{3}$ and $T_{4}$ tracer studies. The thyroid iodine uptake was blocked in all euthyroid and hypothyroid subjects by the administration twice daily of 5 drops of a saturated solution of potassium iodide. In addition to receiving potassium iodide, hyperthyroid subjects received $30-60 \mathrm{mg}$ of methimazole in divided daily doses. Serum was drawn for stable $T_{3}, T_{4}$, and free $T_{4}$ determinations before the in- stitutions of these drugs. After establishing a thyroid blockade, $30-50 \mu \mathrm{Ci}$ of ${ }^{181} \mathrm{I}-\mathrm{T}$, were given intravenously to initiate the study. Timed serum samples were collected twice daily for the next 7 days to measure $T$, disposal rates. 2-4 days after the administration of the $T$, tracer, a pulse dose of $40-100 \mu \mathrm{Ci}$ of ${ }^{125} \mathrm{I}_{-} \mathrm{T}_{3}$ was administered intravenously. Beginning 16-20 hr later, serial serum samples were drawn at 1 - to 2 -hr intervals over a 24 to $36 \mathrm{hr}$ period. In addition, serial timed urine samples were collected at approximately 2 -hr intervals until the completion of the study. The ${ }^{125} \mathrm{I}-\mathrm{T}_{8}$ and ${ }^{181} \mathrm{I}-\mathrm{T}_{4}$ tracers were obtained from Industrial Nuclear Co., St. Louis, Mo.; specific activities were greater than $30 \mu \mathrm{Ci} / \mu \mathrm{g}$ at time of injection. The purity of the radioactive tracers was verified before their administration employing a descending chromatographic paper system utilizing amyl alcohol, $2 \mathrm{~N} \mathrm{NH}_{3}$. The labeled tracers were more than $95 \%$ pure with the majority of the contaminants being labeled iodide. The contaminating iodide was subsequently removed during the processing of the serum samples and standards and therefore did not influence the final results.

Processing of serum samples. Serum ${ }^{125} \mathrm{I}_{-} \mathrm{T}_{3}$ and ${ }^{181} \mathrm{I}-\mathrm{T}_{4}$ were separated from the nonthyronine labeled materials using a $23 \times 0.8 \mathrm{~cm}$ glass column containing $26 \mathrm{~mm}$ of Dowex (Dow Chemical Co., Midland, Mich.) 1-2 X anion exchange resin, 100-200 mesh, acetate cycle (Curtis Nuclear Corporation, Los Angeles, Calif.). Any slow draining columns were replaced, as uniform draining time was essential to obtain reproducible results. Serum samples of 1 $\mathrm{ml}$ each were pipetted into three separate test tubes and 5 $\mathrm{ml}$ of $1.0 \mathrm{~N} \mathrm{NaOH}$ were pipetted into each tube at 2-min intervals. After $5 \mathrm{~min}$ of incubation, each sample was poured into the anion exchange column; each tube was rinsed with approximately $1 \mathrm{ml}$ distilled water which also was poured into the column. After the column had been allowed to drain, the second and third test tubes were poured into the same column in a similar manner. Thus, three successive serum samples were applied to each column. The columns were then washed successively with $1 \%$ acetic acid, three times with $15 \%$ acetic acid, and finally by 0.8 $\mathrm{ml}$ of glacial acetic acid and all eluates discarded. Then, $3 \mathrm{ml}$ of $59 \%$ acetic acid were added to the column, the eluate collected in a counting tube, and the ${ }^{181} \mathrm{I}$ and ${ }^{125} \mathrm{I}$ activities were determined in an automatic well-type scintillation counter employing a dual channel spectrometer (Baird-Atomic, Inc., Cambridge, Mass.). Initial washings of the column with $1 \%$ and $15 \%$ acetic acid served to eliminate contaminating iodoproteins from the test samples. When a serum sample containing ${ }^{181}$ I labeled albumin was passed through the same procedure, no ${ }^{181}$ I activity was measured in the thyronine fraction. Additionally, when a serum sample containing only ${ }^{131}$ I-iodide was used, less than $1 \%$. appeared in the thyronine fraction. Using this procedure, the average recovery for a single run was $58.1 \pm 1.6 \%$ $( \pm \mathrm{SD})$ for ${ }^{125} \mathrm{I}_{-} \mathrm{T}_{8}$ and $54.7 \pm 2.1 \%$ for ${ }^{181} \mathrm{I}_{-} \mathrm{T}_{4}$. Appropriate ${ }^{125} \mathrm{I}_{-} \mathrm{T}_{3}$ and ${ }^{181} \mathrm{I}-\mathrm{T}_{4}$ standards were prepared in pooled unlabeled serum to approximate the same level of activity as that of the test samples and were processed in a similar manner. All serum samples from study subjects were processed in one run in an effort to eliminate the interassay variability. The activities of the ${ }^{181} \mathrm{I}$ and ${ }^{125} \mathrm{I}$ were expressed in terms of per cent of the injected dose per liter and plotted against time on semilogarithmic coordinates. Calculations of the fractional turnover rates, distribution spaces, clearances, and production rates of $T_{4}$ and $T_{3}$ were performed as described by Sterling and Chodos (8).

Processing of urine sample. Each urine sample was col- 
lected in a $250 \mathrm{ml}$ polypropylene bottle containing $3 \mathrm{ml}$ RAI 400 anion exchange resin, chloride cycle, 20-50 mesh (Mallinckrodt Chemical Works, St. Louis, Mo.). The urine was incubated in resin for $24 \mathrm{hr}$ at room temperature to facilitate the uptake of labeled iodide on the resin. Each sample was decanted and the residual resin was transferred to a glass counting vial and counted in a well-type scintillation counter employing a dual channel spectrometer (Baird-Atomic, Inc., Cambridge, Mass.). Net counts for each isotope were expressed as a ratio of ${ }^{125} \mathrm{I} /{ }^{181} \mathrm{I}$ and plotted on semilogarithmic coordinates against time.

Metabolic clearance by constant infusion technique. In five subjects, after completion of the $T_{4}$ and $T_{3}$ pulse tracer studies, the metabolic clearance of $T_{3}$ was measured by techniques similar to those described by Tait and Burstein for steroids (9). A constant infusion consisting of 1 liter of $0.9 \%$ sterile saline solution, to which $25 \mu \mathrm{Ci}{ }^{125} \mathrm{I}_{-} \mathrm{T}_{3}$ and $10 \mu \mathrm{Ci}{ }^{181} \mathrm{I}$ had been added, was administered through an indwelling polyethylene catheter or pediatric scalp vein needle into a peripheral arm vein. Human serum albumin was incorporated into the solution to a final concentration of $0.5 \%$ in order to prevent adsorption of the isotopes to the glassware and intravenous tubing. The infusion rate was approximately $2 \mathrm{ml} / \mathrm{hr}$. A pulse loading dose of ${ }^{125} \mathrm{I}_{-} \mathrm{T}_{3}$, equal in radioactivity to $48 \mathrm{hr}$ of the infusion, and ${ }^{181} \mathrm{I}$, equal in radioactivity to $8 \mathrm{hr}$ of the infusion, was given to expedite tracer equilibration. The constant infusion system employed was a portable roller-type pump (Holter R.D. 044, Holter Company, Bridgeport, Pa.). Isotopic equilibrium was determined by measuring the ratio of ${ }^{125} \mathrm{I}$ to ${ }^{181} \mathrm{I}$ in sequential serum and urine samples; when the serum and urinary ${ }^{125} \mathrm{I} /{ }^{181} \mathrm{I}$ ratio values became constant in three con- secutive hourly samples, isotopic equilibration was assumed to have occurred. Generally this was observed after 14-24 $\mathrm{hr}$ of infusion. The subjects remained supine except when voiding urine samples.

Other laboratory studies performed. Thyroxine iodine by column and "free" thyroxine determinations were performed by Bio-Science Laboratories, Van Nuys, Calif. The maximal binding capacity of TBG was measured by the paper electrophoretic technique described by Ingbar (10). Total stable serum $T_{s}$ concentrations were measured by a radioimmunoassay (RIA) method as described by Chopra, Solomon, and Beall (11). All serum $\mathrm{T}_{3}$ determinations were performed without the knowledge of the patient source. Statistical analysis of the data was performed by a standard $t$ test for nonpaired groups of unequal size.

\section{RESULTS}

Serum $T_{s}$ and $T_{4}$ kinetic data. Fig. 1 illustrates representative examples of serum ${ }^{125} \mathrm{I}_{-} \mathrm{T}_{\mathrm{s}}$ disappearance slopes which were observed in euthyroid subjects and in patients with primary hypothyroidism and thyrotoxic Graves' disease. When plotted on semilogarithmic coordinates, radioactivity data from unextracted serum samples produced a nonlinear and uniformly more shallow disappearance slope than was observed in the corresponding extracted samples. Some of the ${ }^{125} \mathrm{I}$ activity lost in the extraction procedure was ${ }^{125} \mathrm{I}$-iodide. However, since iodides possess a shorter biological half-life than $T_{3}$, the nonparallelism between the slopes

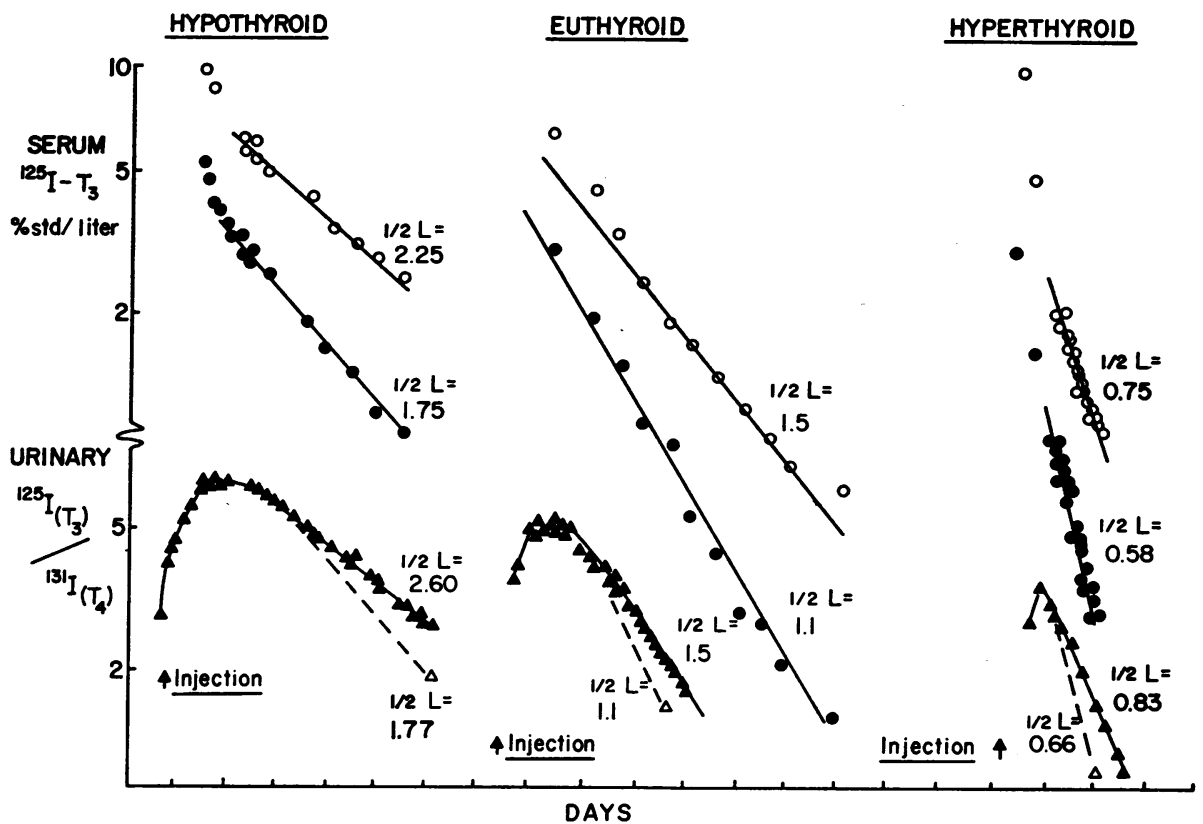

Figure 1 The whole serum (open circles) and extracted serum (closed circles) ${ }^{125} \mathrm{I}-\mathrm{T}_{\mathrm{s}}$ activities are plotted for representative hypothyroid, euthyroid, and hyperthyroid subjects. The injection of the ${ }^{125} \mathrm{I}_{-} \mathrm{T}_{3}$ tracer is denoted by the arrows. The closed triangles in the lower portion of the illustration represent the plot of urinary ${ }^{125} \mathrm{I} /{ }^{121} \mathrm{I}$ values and the dotted lines and open triangles represent the ${ }^{125} \mathrm{I}_{-} \mathrm{T}_{3}$ disappearance slope based on urinary isotope calculation. ( $\frac{1}{2} \mathrm{~L}=$ half-life in days.) 
TABLE I

The Kinetics of Triiodothyronine and

\begin{tabular}{|c|c|c|c|c|c|c|c|c|}
\hline \multirow[b]{2}{*}{ Subject } & \multirow[b]{2}{*}{ Age } & \multirow[b]{2}{*}{ Height } & \multirow[b]{2}{*}{ Weight } & \multicolumn{2}{|c|}{ Serum thyroxine } & \multirow{2}{*}{$\begin{array}{l}\text { Thyroxine- } \\
\text { binding } \\
\text { globulin } \\
\text { capacity }\end{array}$} & \multirow{2}{*}{$\begin{array}{l}\text { Serum } \\
\text { triiodo- } \\
\text { thyronine }\end{array}$} & \multirow{2}{*}{$\begin{array}{c}\text { Triiodothyronine } \\
\text { equilibration } \\
\text { time }\end{array}$} \\
\hline & & & & Total & Free & & & \\
\hline \multicolumn{6}{|l|}{ Normal } & $\mu g / 100 \mathrm{ml}$ & $n g / 100 \mathrm{ml}$ & $h r$ \\
\hline 1 & 58 & 178 & 52 & 4.4 & 1.4 & 14.3 & 55 & 24 \\
\hline 2 & 32 & 178 & 70 & 4.5 & 1.4 & 21.3 & 122 & 22 \\
\hline 3 & 25 & 179 & 112 & 3.5 & 1.2 & - & - & 17 \\
\hline 4 & 35 & 179 & 76 & 4.2 & 1.5 & 20.4 & 120 & 23 \\
\hline 5 & 51 & 163 & 75 & 2.9 & 1.1 & 19.8 & 188 & 27 \\
\hline 6 & 63 & 148 & 68 & 6.8 & 1.8 & 33.3 & 85 & 23 \\
\hline 7 & 54 & 168 & 57 & 5.0 & 1.1 & 28.8 & 105 & 16 \\
\hline 8 & 54 & 173 & 77 & 3.8 & 1.7 & 20.8 & 67 & 24 \\
\hline Mean & 46.5 & 171 & 73.3 & 4.4 & 1.4 & 22.7 & 106 & 22 \\
\hline$\pm \mathrm{SE}$ & 4.9 & 3.9 & 6.4 & 0.4 & 0.1 & 2.4 & 16.7 & 1.3 \\
\hline \multicolumn{9}{|c|}{ Primary hypothyroid } \\
\hline 1 & 63 & 163 & 81 & 0.8 & 0.4 & 28.8 & - & 32 \\
\hline 2 & 51 & 165 & 88 & 2.2 & 0.6 & 20.1 & 52 & 26 \\
\hline 3 & 57 & 173 & 75 & 0.8 & 0.3 & 28.1 & 50 & 34 \\
\hline 4 & 45 & 160 & 55 & 0.5 & 0.3 & 20.5 & 43 & 46 \\
\hline 5 & 43 & 152 & 45 & 0.7 & 0.2 & 20.0 & 30 & 20 \\
\hline 6 & 54 & 150 & 80 & 0.5 & 0.1 & 15.4 & 30 & 39 \\
\hline Mean & 52.2 & 161 & 70.6 & 0.9 & 0.3 & 22.2 & 41 & 33 \\
\hline$\pm \mathrm{SE}$ & 3.1 & 3.5 & 6.9 & 0.3 & 0.1 & 2.1 & 4.7 & 3.8 \\
\hline$P \|$ & - & 一 & - & 0.1 & 0.1 & 0.9 & 0.005 & 0.02 \\
\hline \multicolumn{9}{|c|}{$\begin{array}{l}\text { Graves' disease } \\
\text { Thyrotoxic }\end{array}$} \\
\hline 1 & 36 & 165 & 54 & 15.4 & 8.6 & 22 & 669 & 31 \\
\hline 2 & 25 & 160 & 51 & 8.0 & 4.6 & 18 & 413 & 17 \\
\hline 3 & 19 & 163 & 65 & 7.9 & 2.9 & 20 & 240 & 16 \\
\hline 4 & 25 & 168 & 59 & 7.8 & 2.7 & 18 & 225 & 25 \\
\hline 5 & 30 & 160 & 60 & 6.1 & 2.3 & 28 & 185 & 16 \\
\hline 6 & 32 & 158 & 50 & 3.7 & 1.6 & 15 & 438 & - \\
\hline 7 & 26 & 165 & 70 & 3.9 & 1.4 & 18 & 138 & 28 \\
\hline Mean & 27.6 & 163 & 58 & 7.5 & 3.4 & 20 & 330 & 22 \\
\hline$\pm \mathrm{SE}$ & 2.1 & 1.3 & 2.8 & 1.48 & 0.95 & 1.6 & 70.8 & 2.7 \\
\hline$P \|$ & & & & $<0.1$ & $<0.1$ & $<0.4$ & $<0.01$ & $>0.9$ \\
\hline \multicolumn{9}{|c|}{ Hypothyroid } \\
\hline 1 & 35 & 158 & 62 & 1.9 & 0.9 & 32 & - & 32 \\
\hline 2 & 60 & 142 & 53 & 0.9 & 0.5 & 16 & 75 & 16 \\
\hline 3 & 40 & 168 & 59 & 0.9 & 0.4 & 22 & 75 & 22 \\
\hline Mean & 45 & 156 & 58 & 1.2 & 0.6 & 23 & 75 & 23 \\
\hline$\pm \mathrm{SE}$ & 7.6 & 7.6 & 2.7 & 0.3 & 0.2 & 4.7 & 0 & 4.7 \\
\hline$P \|$ & & & & $<0.01$ & $<0.01$ & $<0.9$ & $<0.2$ & $<0.9$ \\
\hline
\end{tabular}

${ }^{*} \mathrm{kT}_{3}$ and $\mathrm{kT}_{4}$ equal the fractional turnover rate values for $\mathrm{T}_{3}$ and $\mathrm{T}_{4}$ measured in the serum. ${ }^{\mathrm{Ur}} \mathrm{T}_{8}$ and $\mathrm{UkT}_{4}$ represent these same values but measured as the urinary appearance rate of iodide derived from the deiodination of $T_{3}$ and $T_{4}$. $\ddagger T_{3} M C R$, Metabolic clearance rate of $T_{3}$ determined by constant infusion.

$\$$ Thyroxine iodine values multiplied by 1.53 to give total hormone when calculating thyroxine disposal rate.

\| $P$ value refers to the significance of the difference compared to normal group. 
Thyroxine Peripheral Metabolism

\begin{tabular}{|c|c|c|c|c|c|c|c|c|c|c|}
\hline $\mathrm{kT}_{\mathbf{4}}$ & $\mathrm{kT}_{\mathbf{3}}$ & $\mathrm{vE}_{\mathbf{3}}$ & $\mathrm{UkT}_{3} / \mathrm{T}_{4}$ & $T_{4}$ & $T_{3}$ & $T_{4}$ & $T_{2}$ & $\begin{array}{c}T_{4} \ddagger \\
M C R\end{array}$ & $T, 8$ & $T_{3}$ \\
\hline \multicolumn{4}{|c|}{$\% / 24 \mathrm{hr}$} & \multicolumn{2}{|c|}{ liters } & \multicolumn{3}{|c|}{ liters/24 hr } & \multicolumn{2}{|c|}{$\mu g / 24 \mathrm{hr}$} \\
\hline 11.7 & 88 & 87 & 75 & 11.6 & 37.2 & 1.36 & 32.7 & - & 91.5 & 18.0 \\
\hline 12.6 & 77 & 78 & 65 & 12.6 & 40.0 & 1.59 & 30.8 & - & 109.5 & 37.6 \\
\hline 10.5 & 63 & 58 & 46 & 11.9 & 36.0 & 1.25 & 22.7 & - & 67.0 & - \\
\hline 14.4 & 69 & 71 & 60 & 10.8 & 40.5 & 1.56 & 27.9 & 28.0 & 100.2 & 33.5 \\
\hline 9.6 & 59 & 59 & 50 & 9.1 & 38.2 & 0.87 & 22.5 & 28.1 & 38.6 & 42.3 \\
\hline 9.4 & 60 & 63 & 48 & 15.0 & 35.0 & 1.41 & 21.0 & - & 146.7 & 17.9 \\
\hline 9.3 & 69 & 69 & 58 & 10.8 & 38.7 & 1.00 & 26.3 & - & 76.5 & 27.6 \\
\hline 11.9 & 58 & 53 & 42 & 11.3 & 41.7 & 1.34 & 24.2 & - & 77.9 & 16.2 \\
\hline 11.2 & 67.9 & 67.3 & 55.5 & 11.6 & 38.4 & 1.30 & 26.1 & - & 88.5 & 27.6 \\
\hline \multirow[t]{2}{*}{0.6} & 3.7 & 4.0 & 3.9 & 0.6 & 0.8 & 0.09 & 1.5 & - & 11.5 & 3.99 \\
\hline & 1 & & & & & & & & & \\
\hline 9.5 & 43 & 36 & 26 & 23.8 & 38.3 & 2.26 & 16.5 & - & 27.7 & - \\
\hline 7.2 & 41 & 50 & 43 & 17.5 & 38.0 & 1.26 & 15.6 & 13.0 & 42.4 & 8.11 \\
\hline 8.1 & 40 & 35 & 27 & 11.8 & 41.7 & 0.96 & 16.7 & 16.3 & 11.8 & 8.35 \\
\hline 8.5 & 66 & 54 & 45 & 8.8 & 33.3 & 0.75 & 22.0 & - & 5.74 & 9.46 \\
\hline 11.3 & 63 & 53 & 42 & 14.9 & 35.3 & 1.68 & 22.2 & - & 18.1 & 6.66 \\
\hline 10.5 & 46 & 39 & 29 & 11.5 & 39.2 & 1.21 & 18.0 & - & 9.26 & 5.40 \\
\hline 9.2 & 50 & 45 & 35 & 14.7 & 37.6 & 1.35 & 18.5 & - & 19.2 & 7.60 \\
\hline 0.6 & 4.7 & 3.6 & 3.6 & 2.2 & 1.2 & 0.22 & 1.2 & - & 5.6 & 0.71 \\
\hline 0.05 & 0.01 & 0.01 & 0.01 & 0.2 & 0.6 & 0.9 & 0.01 & - & 0.01 & 0.001 \\
\hline 17.3 & 119 & 86 & 69 & 9.5 & 45.5 & 1.64 & 54 & 47 & 386 & 361 \\
\hline 26.9 & 119 & 111 & 84 & 17.4 & 90.9 & 4.68 & 108 & - & 573 & 446 \\
\hline 18.5 & 84 & 111 & 92 & 12.0 & 60.0 & 2.22 & 50 & - & 268 & 120 \\
\hline 13.9 & 95 & 83 & 69 & 13.9 & 42.0 & 1.93 & 40 & - & 230 & 90 \\
\hline 27.0 & 138 & 125 & 92 & 17.4 & 40.0 & 4.70 & 55 & - & 439 & 102 \\
\hline 21.9 & 84 & 74 & 52 & 12.1 & 53.0 & 2.65 & 45 & - & 150 & 197 \\
\hline 21.6 & 131 & 105 & 83 & 9.6 & 49.3 & 2.07 & 65 & - & 124 & 89.7 \\
\hline $\begin{array}{c}21.0 \\
1.84\end{array}$ & $\begin{array}{l}110 \\
8.4\end{array}$ & $\begin{array}{r}99.3 \\
7.0\end{array}$ & $\begin{array}{r}77.3 \\
5.5\end{array}$ & $\begin{array}{c}13.1 \\
1.24\end{array}$ & $\begin{array}{r}54.4 \\
6.6\end{array}$ & $\begin{array}{l}2.84 \\
0.49\end{array}$ & $\begin{array}{l}60 \\
8.6\end{array}$ & - & $\begin{array}{l}310 \\
61.7\end{array}$ & $\begin{array}{r}201 \\
54.9\end{array}$ \\
\hline$<0.01$ & $<0.01$ & $<0.01$ & $<0.01$ & $<0.3$ & $<0.05$ & $<0.01$ & $<0.01$ & - & $<0.01$ & $<0.01$ \\
\hline 10.2 & 49 & 54 & 44 & 11.3 & 53.0 & 1.15 & 26 & - & 33.5 & - \\
\hline 13.0 & 51 & 63 & 50 & 7.4 & 30.1 & 0.96 & 15 & - & 13.2 & 11.3 \\
\hline 12.4 & 72 & 53 & 41 & 9.7 & 42.5 & 1.20 & 31 & - & 16.5 & 23.3 \\
\hline 11.9 & 57.3 & 56.7 & 45 & 9.5 & 41.9 & 1.10 & 24 & - & 21.1 & 17.3 \\
\hline 0.9 & 7.4 & 3.2 & 2.6 & 1.1 & 6.6 & 0.07 & 4.7 & - & 6.3 & 6.0 \\
\hline$<0.6$ & $<0.3$ & $<0.1$ & $<0.1$ & $<0.2$ & $<0.7$ & $<0.2$ & $<0.7$ & - & $<0.01$ & $<0.2$ \\
\hline
\end{tabular}


TABLE $1-$

\begin{tabular}{|c|c|c|c|c|c|c|c|c|}
\hline \multirow[b]{2}{*}{ Subject } & \multirow[b]{2}{*}{ Age } & \multirow[b]{2}{*}{ Height } & \multirow[b]{2}{*}{ Weight } & \multicolumn{2}{|c|}{ Serum thyroxine } & \multirow{2}{*}{$\begin{array}{l}\text { Thyroxine- } \\
\text { binding } \\
\text { globulin } \\
\text { capacity }\end{array}$} & \multirow{2}{*}{$\begin{array}{l}\text { Serum } \\
\text { triiodo } \\
\text { thyroninr }\end{array}$} & \multirow{2}{*}{$\begin{array}{c}\text { Triodothyronine } \\
\text { equilibration } \\
\text { time }\end{array}$} \\
\hline & & & & Total & Free & & & \\
\hline & $y r$ & $\mathrm{~cm}$ & $k g$ & $\mu \mathrm{g} / 100 \mathrm{ml}$ & $n g / 100 m l$ & $\mu \mathrm{g} / 100 \mathrm{ml}$ & $n g / 100 \mathrm{ml}$ & $\mathrm{hr}$ \\
\hline \multicolumn{9}{|c|}{ Factitial hyperthyroid } \\
\hline 1 & 25 & 178 & 77 & 10.3 & 4.8 & 27 & - & 24 \\
\hline 2 & 45 & 163 & 65 & 8.7 & 3.6 & - & 128 & 19 \\
\hline 3 & 41 & 173 & 77 & 8.0 & 3.6 & 29 & 285 & 25 \\
\hline Mean & 37 & 171 & 73 & 9.0 & 4.0 & 28 & 207 & 23 \\
\hline$\pm \mathrm{SE}$ & 6.1 & 4.4 & 4 & 0.7 & 0.4 & - & 78.5 & 1.9 \\
\hline$P \|$ & & & & $<0.01$ & $<0.01$ & - & $<0.3$ & $<0.8$ \\
\hline \multicolumn{9}{|c|}{ Idiopathic elevated thyroxine-binding globulin } \\
\hline 1 & 67 & 162 & 91 & 8.4 & 1.7 & 41 & 288 & 29 \\
\hline 2 & 46 & 168 & 125 & 6.8 & 1.7 & 37 & 150 & 31 \\
\hline 3 & 43 & 152 & 45 & 8.4 & 2.0 & 57 & 110 & 26 \\
\hline 4 & 38 & 173 & 59 & 5.5 & 1.5 & 43 & 120 & 43 \\
\hline Mean & 49 & 164 & 80 & 7.3 & 1.7 & 44.5 & 167 & 32 \\
\hline$\pm \mathrm{SE}$ & 6.4 & 4.5 & 18 & 0.7 & 0.1 & 4.4 & 41.2 & 3.5 \\
\hline$P \|$ & & & & 0.01 & 0.05 & $<0.01$ & 0.3 & 0.05 \\
\hline \multicolumn{9}{|c|}{ Idiopathic low thyroxine-binding globulin } \\
\hline 1 & 60 & 163 & 50 & 0.9 & 1.6 & 2 & 40 & 29 \\
\hline 2 & 53 & 178 & 70 & 1.0 & 1.0 & 10 & 40 & 16 \\
\hline
\end{tabular}

of the data plotted from nonextracted and extracted serum could not be explained solely on this basis. The generation of ${ }^{125} \mathrm{I}$ labeled iodoproteins from $\mathrm{T}_{3}$ would more likely account for this flattening of the disappearance curve of the unextracted sera (6). The linearity observed in the extracted ${ }^{125} \mathrm{I}-\mathrm{T}_{\mathrm{s}}$ serum slope suggests that such contamination had been effectively eliminated by column extraction.

In the euthyroid subjects, the daily fractional turnover rate for $\mathrm{T}_{8}\left(\mathrm{kT}_{8}\right)$ in the extracted serum was $67.9 \%$. In the primary hypothyroid group, $\mathrm{kT}_{\mathrm{s}} \mathrm{de}-$ creased to $49.8 \%$, while in the thyrotoxic Graves' and factitial hyperthyroid groups $\mathrm{kT}_{8}$ increased to 110 and $98.3 \%$, respectively. Insignificant changes in $\mathrm{kT}_{8}$ were seen in the hypothyroid Graves' disease patients and subjects with idiopathic alterations in TBG. These findings are consistent with the conclusion that kT3 is affected by alterations in metabolic status, independent of changes in circulating TBG values. In these same subjects, kT * was affected similarly by alterations in metabolic status, but $\mathrm{kT}_{\text {4 }}$ was also altered by changes in serum TBG levels.

Analysis of urinary ${ }^{125} I /{ }^{131} I$ turnover kinetics. Representative samples of the urinary ${ }^{125} \mathrm{I} /{ }^{181} \mathrm{I}$ ratio plots are shown in Figs. 1 and 2 . Since ${ }^{125} \mathrm{I}_{-} \mathrm{T}_{3}$ and ${ }^{181} \mathrm{I}_{-} \mathrm{T}_{4}$ normally are excluded from the urine, measurement of the urinary ${ }^{125} \mathrm{I} /{ }^{181} \mathrm{I}$ ratio reflects the deiodination of the precursor labeled hormones, namely, ${ }^{125} \mathrm{I}-\mathrm{T}_{\mathbf{3}}$ and ${ }^{181} \mathrm{I}_{-} \mathrm{T}_{4}$ (12).

The slope described by the urinary ${ }^{125} \mathrm{I} /{ }^{181} \mathrm{I}$ values after injection of ${ }^{125} \mathrm{I}-\mathrm{T}_{\mathrm{s}}$ can be divided into three phases. The first phase describes the equilibration of ${ }^{125} \mathrm{I}_{-} \mathrm{T}_{3}$ in the extrathyroidal $\mathrm{T}_{3}$ pool. This phase was characterized by a rapid increase in the ${ }^{125} \mathrm{I} /{ }^{121} \mathrm{I}$ urinary values. The point at which the urinary ${ }^{125} \mathrm{I} /{ }^{121} \mathrm{I}$ values formed a linear exponential slope can be taken as the time when the $T_{8}$ tracer had achieved full equilibration; this time interval was observed to be $22 \mathrm{hr}$ in euthyroid subjects. It was not significantly altered in any of the study groups except in those patients with high TBG levels and patients with primary hypothyroidism; in these groups $T_{8}$ equilibrium was prolonged for approximately $10 \mathrm{hr}$ beyond the normal control values.

The second phase was marked by the ${ }^{125} \mathrm{I} /{ }^{121} \mathrm{I}$ urinary ratio values forming a linear slope on semilogarithmic coordinates (as illustrated in Figs. 1 and 2). Since this slope $\left({ }^{\mathrm{U}} \mathrm{T}_{3} / \mathrm{T}_{4}\right)$ represented the ratio of the fractional turnover rates of the labeled precursor hormones (i.e., ${ }^{125} \mathrm{I}_{-} \mathrm{T}_{3}$ and ${ }^{181} \mathrm{I}-\mathrm{T}_{4}$ ), it was possible to mathematically derive the fractional turnover rate of serum ${ }^{125} \mathrm{I}_{-} \mathrm{T}_{3}$ by the following analysis:

Assuming that the urinary ${ }^{125} \mathrm{I} /{ }^{181} \mathrm{I}$ slope was the result of two declining exponential functions, the mathemati- 


\begin{tabular}{|c|c|c|c|c|c|c|c|c|c|c|}
\hline & & & & Di. & & & arance rate & & & \\
\hline & & & & & & & & & Produc & on rate \\
\hline $\mathrm{kT}_{4}$ & $k T_{3}$ & $\mathrm{UkT}_{3}$ & $\operatorname{vr} T_{3} / T_{4}$ & $T_{4}$ & $T_{3}$ & $T_{4}$ & $T_{8}$ & MCR & $T / 8$ & $T_{3}$ \\
\hline & & & & & & & iters $/ 24 \mathrm{hr}$ & & & \\
\hline 15.1 & 93 & 75 & 60 & 11.8 & 51 & 1.78 & 47 & - & 280 & - \\
\hline 15.2 & 83 & 84 & 69 & 12.0 & 59 & 1.82 & 49 & - & 242 & 62.7 \\
\hline 16.1 & 119 & 106 & 90 & 16.4 & 50 & 2.64 & 60 & - & 323 & 171 \\
\hline 15.5 & 98.3 & 88.3 & 73 & 13.4 & 53 & 2.08 & 52 & - & 282 & 117 \\
\hline 0.3 & 10.7 & 9.2 & 8.9 & 1.5 & 2.8 & 0.28 & 4 & - & 23 & 54 \\
\hline$<0.01$ & $<0.05$ & $<0.1$ & $<0.2$ & $<0.3$ & $<0.01$ & $<0.05$ & $<0.01$ & - & $<0.01$ & $<0.2$ \\
\hline 7.1 & 64 & 62 & 55 & 7.9 & 19 & 0.56 & 12 & - & 72 & 34.6 \\
\hline 8.0 & 50 & 49 & 41 & 7.9 & 30 & 0.63 & 15 & - & 66 & 22.5 \\
\hline 6.8 & 69 & 66 & 59 & 8.6 & 27 & 0.58 & 19 & - & 75 & 20.9 \\
\hline 9.2 & 59 & 55 & 46 & 7.8 & 28 & 0.72 & 17 & - & 61 & 20.4 \\
\hline 7.8 & 60.5 & 58 & 50 & 8.1 & 26 & 0.62 & 16 & - & 68 & 24.6 \\
\hline 0.5 & 4.1 & 3.8 & 4.1 & 0.2 & 2.4 & 0.04 & 1.5 & - & 3.1 & 3.4 \\
\hline$<0.01$ & $<0.3$ & $<0.2$ & $<0.4$ & $<0.01$ & $<0.01$ & $<0.01$ & $<0.1$ & - & $<0.2$ & $<0.6$ \\
\hline 28.9 & 82 & 66 & 37 & 13.1 & 55 & 3.79 & 45 & - & 52 & 18 \\
\hline 23.7 & 75 & 64 & 40 & 21.9 & 74 & 5.19 & 56 & - & 64 & 22 \\
\hline
\end{tabular}

cal expression for the ratio of two different equations can be written:

$$
\frac{{ }^{125} \mathrm{I}}{{ }^{131} \mathrm{I}}=\frac{\mathrm{A}_{1} \mathrm{e}^{-U k} \mathrm{~T}_{3}{ }^{\mathrm{t}}}{\mathrm{A}_{2} \mathrm{e}^{-U \mathrm{k}} \mathrm{T}_{4}{ }^{\mathrm{t}}}=\mathrm{A}_{3} \mathrm{e}^{-U \mathrm{k}} \mathrm{T}_{3} / \mathrm{T}_{4}{ }^{\mathrm{t}},
$$

where ${ }^{125} \mathrm{I}$ and ${ }^{181} \mathrm{I}$ represent urinary ${ }^{125} \mathrm{I}$ and ${ }^{131} \mathrm{I}$ values at any time $t ; A_{1}, A_{2}$, and $A_{3}$ are constants, ${ }^{{ }^{0}} T_{3}$ and ${ }^{\mathrm{vk}} \mathrm{T}_{4}$ are the urinary fractional turnover rates for ${ }^{125} \mathrm{I}_{-} \mathrm{T}_{3}$ and ${ }^{181} \mathrm{I}-\mathrm{T}_{4}$, respectively. Thus :

$$
\begin{aligned}
& -\left({ }^{\mathrm{Uk}} \mathrm{T}_{3}-{ }^{\mathrm{Uk}} \mathrm{T}_{3}\right)={ }^{\mathrm{Uk}} \mathrm{T}_{3} / \mathrm{T}_{4}, \\
& { }^{\mathrm{Uk}} \mathrm{T}_{4}+{ }^{\mathrm{Uk}} \mathrm{T}_{3} / \mathrm{T}_{4}={ }^{\mathrm{Uk}} \mathrm{T}_{3}={ }^{\mathrm{k}} \mathrm{T}_{3},
\end{aligned}
$$

where ${ }^{\mathrm{v}} \mathrm{T}_{3} / \mathrm{T}_{4}$ can be obtained directly from the urinary ratio slope and ${ }^{\mathrm{V}} \mathrm{T}$, can be assumed to equal the fractional turnover rate of $T_{4}$ measured in serum $\left(k T_{4}\right)$. As seen in Fig. 1 and Table $I$, ${ }^{\mathrm{dx}} \mathrm{T}_{\mathbf{s}}$ values closely correlated with $(r=0.91, P<0.001)$ the corresponding serum $\mathrm{kT}_{3}$ measurements. This served to verify the accuracy of the direct serum $\mathrm{kT}_{\mathbf{s}}$ measurements.

Although $\mathrm{kT}_{3}$ and ${ }^{\mathrm{vk}} \mathrm{T}_{3}$ were similar, it is of interest that ${ }^{{ }^{k}} T_{s}$ values were generally less than the corresponding serum $\mathrm{kT}_{3}$ determinations. This difference, which averaged $7.3 \%$ in all of the study groups, was found to be significant on paired $t$ test $(P<0.001)$. It probably can be accounted for, in part, by the distorting effect of ${ }^{125} \mathrm{I}$ iodoproteins produced from the labeled $T_{3}$
(6). Assuming that the fraction degradation rate of the labeled iodoprotein is much less than that of labeled triiodothyronine, it would be expected that gross alterations in urinary ${ }^{125} \mathrm{I} /{ }^{121} \mathrm{I}$ ratio slope values would not be seen until the majority of the injected ${ }^{125} \mathrm{I}-\mathrm{T}_{3}$ tracer had disappeared. Indeed, a loss of linearity of the urinary slope values was not observed until 5-10 days after the injection of ${ }^{125} \mathrm{I}_{-} \mathrm{T}_{3}$ tracer which denoted the beginning of the third phase.

The ${ }^{\mathrm{U} \times} \mathrm{T}_{3} / \mathrm{T}_{4}$ value in the second phase also provided an index of the relative fractional turnover rates of ${ }^{125} \mathrm{I}_{-} \mathrm{T}_{3}$, as compared to ${ }^{181} \mathrm{I}-\mathrm{T}_{4}$. A marked increase in this ratio value was noted in the factitial hyperthyroid and toxic Graves' disease groups, while lower values were evident in the patients with primary hypothyroidism and those with idiopathically low TBG levels. A rise in the ${ }^{{ }^{0}} \mathrm{~T}_{3} / \mathrm{T}_{4}$ value would indicate that the change in fractional turnover rate for $T_{8}$ was greater than that for $T_{4}$. It is apparent from Table $I$ and Fig. 2 that hyperthyroidism accelerates $T_{3}$ degradation to a greater degree than $T_{4}$ and that the reverse is true in hypothyroidism. An exception was the decrease in the ${ }^{\mathrm{N}} \mathrm{T}_{3} / \mathrm{T}_{4}$ values seen in the idiopathic low $\mathrm{TBG}$ group which resulted from an increase in $T_{4}$ degradation rather than a decrease in the $T_{3}$ degradation.

In the third phase, the urinary ratio values were observed to become fixed or to rise with time. This 


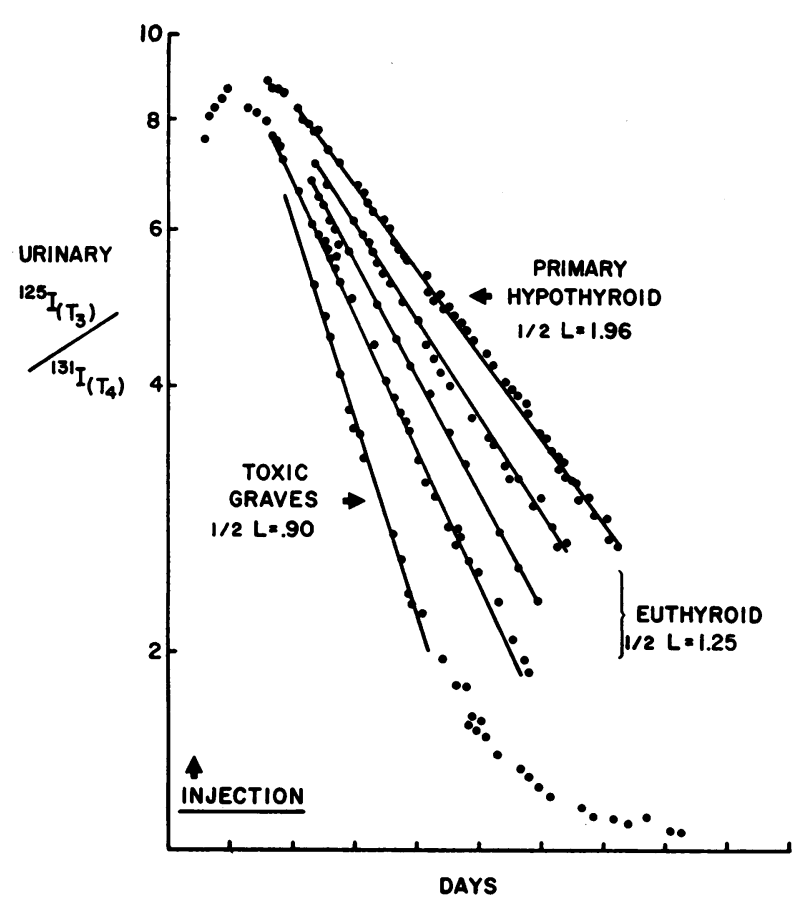

FIGURE 2 Urinary ${ }^{125} \mathrm{I} /{ }^{121} \mathrm{I}$ values are plotted after the injection of ${ }^{125} \mathrm{I}-\mathrm{T}_{3}$ in euthyroid subjects and in representative patients with thyrotoxic Graves' disease or primary hypothyroidism. ( $\frac{1}{2} \mathrm{~L}=$ half-life in days.)

indicated that the precursor to the ${ }^{125} \mathrm{I}$-iodide in the urine possessed a biological half-life greater than that of ${ }^{181} \mathrm{I}-\mathrm{T}$, or, in other words, greater than 7 days on the average. This would be consistent with the estimated biological half-life of 12-15 days for the albumin-like labeled material produced as a by-product of $T_{3}$ degradation (6).

Distribution space of $T_{3}(T, D S)$ and $T_{4}(T, D S)$. In euthyroid subjects $T_{8} D S$ was $38.4 \pm 0.8$ liters and the $\mathrm{T}$. DS was $11.6 \pm 0.6$ liters ( $\pm \mathrm{SEM}$ ). The $\mathrm{T}_{3} \mathrm{DS}$ was increased to $64.5 \pm 9.5$ liters in the low TBG group and to $54.4 \pm 6.6$ liters in the thyrotoxic Graves' disease patients, while it was reduced to $26.0 \pm 2.4$ liters in subjects with elevated TBG values. The $T_{8} D S$ was not significantly altered in the other study groups. It should be noted that the TBG levels in hypothyroid patients were not significantly different from those seen in the control group. The T, DS generally paralleled the alterations in $T_{8} \mathrm{DS}$ in the various clinical states studied, but the changes were small and with the exception of subjects with elevated TBG levels, were not statistically significant.

The ratio of $T_{8} D S / T_{4} D S$ was 3.31 in the euthyroid group and was not changed in subjects with altered TBG levels. There was a tendency in hyper- and hypothyroid states for respective increases and decreases in this ratio value to occur (4.15 in hyperthyroid Graves',
2.55 in primary hypothyroid subjects, $P<0.05$ ). Thus, it appears that alterations in circulating TBG levels similarly affect the distribution spaces for $T_{3}$ and $T_{4}$, while changes in metabolic state alter $T_{3} D S$ to a greater extent than T. DS. Additionally, an increased $\mathrm{T}_{3} \mathrm{DS} / \mathrm{T}$. DS ratio of 4.41 was observed in hypothyroid Graves' disease subjects.

$T$ s and $T$, clearances. In the euthyroid group, $T_{8}$ clearance was found to be $26.1 \pm 1.5$ liters and $T$, clearance to be $1.3 \pm 0.09$ liters/day. In thyrotoxicosis, $T_{s}$ and $T_{\text {. clearances were both significantly increased to }}$ 60 and 2.8 liters and the converse of 18.5 and 1.35 liters was present in the hypothyroid patients. In the group with elevated TBG values, $T_{3}$ and $T_{4}$ clearances were decreased to 0.62 , while they were markedly increased in two subjects with low TBG levels.

Metabolic clearance rate determinations. In five study subjects (two controls, two hypothyroid, and one hyperthyroid patient), $T_{s}$ metabolic clearance rate was determined by employing a constant infusion of ${ }^{125} \mathrm{I}-\mathrm{T}_{\mathrm{s}}$. Generally, there was excellent correlation $(r=0.96$, $P<0.01)$ between the values as determined by the pulse tracer technique and the constant infusion method (Table I).

Hormomal production. In the euthyroid control group, daily blood production rates were $28 \mu \mathrm{g}$ for $\mathrm{T}_{\mathrm{s}}$ and $88 \mu \mathrm{g}$ for T. As might be expected, these values were not altered in euthyroid subjects with idiopathically high or low TBG values. In contrast, a $3 \frac{1}{2}$-fold increase in $T_{4}$ and over a 7 -fold increase in $T_{8}$ production rate was found in the thyrotoxic Graves' disease patients which gave a ratio of $\mathrm{T}_{3}$ to $\mathrm{T}_{4}$ production of $0.64(P<0.05)$. This preferential $\mathrm{T}_{\mathrm{s}}$ production was seen most prominently in the hypometabolic Graves' disease patients where the $T_{s}$ to $T_{4}$ production ratio was increased to 0.81 . In the primary hypothyroid group, there was a 4 -fold decrease in both $T_{3}$ and $T_{4}$ production rates.

\section{DISCUSSION}

The method for measurement of serum $T_{s}$ kinetics described in this study appears to combine both technical simplicity and accuracy. Although solvent extraction methods $(6,12)$ could have been employed, the anion exchange column system proved to be less time consuming and more reproducible to cleanly separate labeled iodoproteins and iodothyronines. Substantiation that the column method achieved this goal was revealed by the following findings: (a) serum ${ }^{125} \mathrm{I}-\mathrm{T}_{\mathrm{s}}$ disappearance curves were linear when plotted on semilogarithmic coordinates (Figs. 1 and 2); (b) the mathematical analysis of urinary ${ }^{125} \mathrm{I} /{ }^{121} \mathrm{I}$ values verified the accuracy of the serum $T_{s}$ turnover measurements; (c) studies of the metabolic clearance rate (MCR) of $\mathrm{T}_{3}$ by con- 
stant infusion closely approximated the results obtained by pulse $T_{\mathrm{a}}$ kinetic studies.

The fractional turnover rates observed for $T_{3}$ in this study substantially differed from those reported by Woeber, Sobel, Ingbar, and Sterling (5) in hyperthyroidism and by Zaninovich, Volpe, and Ezrin in subjects with altered TBG states (4). Either the failure to appreciate (4), or adequately compensate for (5), the presence of iodoproteins formed from $\mathrm{T}_{\mathbf{3}}$ degradation may have been responsible for these differences. With the exception of the limited data reported by Surks and Oppenheimer (6), it is evident that all previously reported labeled $T_{8}$ disappearance curves, whether in serum $(2-5,13-15)$ or in the whole body studies (16), suffer from the same technical problem of failure to eliminate the influence of iodoproteins.

Estimates of $T_{3}$ distribution space ( $\left.T_{3} D S\right)$ may be in error since the single compartmental model system used in this study assumes that $T_{3}$ disposal during equilibration is the same as after equilibration. The observed rise in urinary ${ }^{125} \mathrm{I} /{ }^{120} \mathrm{I}$ ratio values during the equilibration phase (Figs. 1 and 2 ) indicated that $T_{3}$ deiodination was substantially less during than after equilibration. Since deiodination constitutes the major route of degradation for $T_{3}$, this would result in an underestimation of $T_{z}$ disposal during the equilibration and, in turn, would cause an underestimation of $T_{3} D S$. On the other hand, the serum $T_{8}$ disappearance slope during the equilibration phase may reflect the clearance of the $T_{3}$ tracer, and this must be considered in calculating MCR. This error can be compensated for by using a two compartmental model (9). An apparent $20 \%$ overestimation of $\mathrm{T}_{3} \mathrm{DS}$ would result in normal subjects if a single rather than a two compartmental model system were used (15).

In spite of these potential shortcomings, the magnitude of error in calculating MCR using the single compartmental model method would not appear to be great. Similar MCR values were obtained in five of our subjects by the constant infusion method which does not suffer from these technical handicaps. Moreover, Cavalieri, Steinberg, and Searle (17) have recently presented values for $T_{3} M C R$ using the constant infusion method in normal and Graves' disease subjects which closely approximated the values seen in our patient population. Their $\mathrm{T}_{3}$ MCR values were 26.0 liters/day in euthyroid and 52.3 liters/day in toxic Graves' disease subjects while our values were 26.1 liters/day and 60.0 liters/day, respectively. The reason that the single compartmental model model appears to satisfactorily approximate $T_{8}$ clearance is that the loss of the $T_{3}$ tracer during the equilibration phase appears to be relatively small until the tracer approaches its ultimate distribution volume. In other words, the rapid equilibrating compartments do not represent major sites for $\mathrm{T}_{\mathbf{3}}$ disposal.

Comparison of $T_{8}$ and $T_{4}$ kinetics revealed differences as well as similarities in peripheral metabolism. It was observed that $\mathrm{kT}_{\mathbf{3}}$ and $\mathrm{kT}_{4}$ were altered in a parallel manner by changes in metabolic rate and TBG levels, but that alterations in metabolic status seemed to influence $\mathrm{kT}_{3}$ to a greater extent than $\mathrm{kT}_{4}$, while changes in TBG altered $k T_{4}$ to a greater degree than $\mathrm{kT}_{3}$. Since $T_{s}$ and $T_{4}$ appear to be bound by TBG extracellularly, it is fair to assume that the extracellular distribution space for $T_{3}$ is equal to that of $T_{4}$, or about 5 liters (18). Thus, only about $15 \%$ of the entire extrathyroidal $\mathrm{T}_{3}$ pool would appear to be extracellular. It is not surprising, therefore, that $T_{3}$ is affected by changes in metabolic status since it is predominantly an intracellular hormone. On the other hand, approximately $50 \%$ of the $T_{*}$ is in the extracellular fluid compartment bound to TBG (18), and it is equally logical that TBG alterations will influence $k \mathrm{~T}$, to a greater degree than $\mathrm{kT}_{3}$. Therefore, one may conclude that the differences in the magnitude of change in $\mathrm{kT}_{3}$ and $\mathrm{kT}$ observed in the various study groups are best explained by the differences in the extrathyroidal distribution of these two hormones. Oppenheimer, Schwartz, Shapiro, Bernstein, and Surks have come to essentially the same conclusions from the study of $T_{3}$ and $T_{4}$ peripheral metabolism in four euthyroid subjects (19).

However, several other aspects of $T_{3}$ and $T_{4}$ peripheral metabolism are less clear. For instance, why is the $T_{3}$ distribution space $3 \frac{1}{2}$ times greater than that for $T_{4}$ ? Since the extracellular binding for $T_{8}$ and $T_{4}$ are predominantly to TBG and the intrahepatic distribution space for $T_{\text {t }}$ is estimated to be greater than that for $T_{3}(20)$, this difference is even more puzzling. Additionally, why was $T_{3}$ equilibration delayed as long as $22 \mathrm{hr}$ in euthyroid subjects? Presumably this relates to the slow entrance of $T_{3}$ into the extrahepatic intracellular compartment. As has been observed by Cavalieri, Steinberg, and Searle (20), the egress of $T_{8}$ into this compartment is quite slow and, as we confirmed in the present study, is not altered by hypermetabolic states or by decreases in circulating TBG concentrations. Thus, it would appear that future investigation will be necessary to solve these puzzling observations.

The measurement of $T_{8}$ concentration in the serum has been technically difficult and still must be considered an area of controversial investigation (21-27). It would appear that the values previously reported by the method of Sterling, Bellabarba, Newman, and Brenner may be erroneously high (23). We have recently developed a double-column chromatographic method for measurement of serum $T_{3}$ concentration which allowed correction for some of the methodological artifacts, particu-

Thyroxine and Triiodothyronine Kinetics 481 
larly the monodeiodination of $T_{4}$ to $T_{3}$ (28). This has provided a more accurate assessment of serum $T_{3}$ concentration, but the correction factors are large and the results are, therefore, subject to some overcorrection, particularly at low serum $T_{3}$ levels. The recent development of a radioimmunoassay method for measurement of serum $\mathrm{T}_{3}$ in unextracted serum would therefore appear to represent a substantial methodological improvement (11).

The apparently inappropriately high $\mathrm{kT}_{3}$ and $\mathrm{kT}_{4}$ values found in Graves' disease subjects with normal and subnormal $T_{4}$ values, requires some further clarification. A high $\mathrm{kT}_{4}$ value relative to metabolic status in patients with treated Graves' disease was initially described by Ingbar and Freinkel (29). Subsequent investigations have substantiated this observation and have indicated that an augmentation in hepatic $T_{4}$ incorporation and degradation are probably responsible for the elevated $\mathrm{kT}_{4}$ values $(30,31)$. Recently, Schussler and Vance (32) and Farmer, Smitherman, Beschi, and Pittman (33) have demonstrated that $\mathrm{T}_{\mathbf{s}}$ administration to euthyroid subjects, in replacement or subreplacement doses, is capable of increasing $\mathrm{kT}_{4}$, implying that $T_{3}$ is capable of increasing the rate of $T_{4}$ degradation. Additionally, Sterling and coworkers have reported elevated serum $\mathrm{T}_{3}$ values in treated Graves' disease subjects in whom serum $T_{4}$ values have returned to normal or hypothyroid levels (23). In the present study the following observations would appear to be relevant: $(a)$ increases in the $\mathrm{T}_{3} \mathrm{DS} / \mathrm{T}_{4} \mathrm{DS}$ and $\mathrm{T}_{3} / \mathrm{T}_{4}$ production ratios were found in the hypothyroid Graves' disease group; $(b)$ a positive correlation between $\mathrm{T}_{\mathbf{s}}$ production rate and $\mathrm{kT}_{4}$ was observed $(r=0.72, P<$ 0.001 ) when excluding altered TBG states; (c) two thyrotoxic Graves' disease patients, who displayed normal free and total $T_{4}$ values with elevated serum $T_{3}$ levels, had rapid $T_{3}$ and $T_{4}$ kinetics similar to those of the remainder of the patients with thyrotoxic Graves' disease; $(d)$ patients with factitial thyrotoxicosis evidenced the same kinetic changes for $T_{3}$ and $T_{4}$ as were observed in the thyrotoxic Graves' disease group. Thus, it would appear that the presence of a large fractional turnover rate for $T_{4}$ in treated Graves' disease patients may not represent, as previously speculated, an expression of "an integral part of this disorder per se" (34), but rather it is probably a manifestation of a preferential $\mathrm{T}_{3}$ secretion present in this condition.

It is evident from the foregoing discussion that $T_{3}$ production plays a major role in determining the pattern of $T_{3}$ and $T_{4}$ kinetics. Additionally, $T_{3}$ production would appear to have a considerable influence on peripheral hormone action. If one assumes that $T_{3}$ has 4 times the metabolic potency of $T_{4}$, then $T_{3}$ might account for more than half of all hormonal activity pro- duced in euthyroid subjects and, in the case of Graves' disease patients, it could account for better than three fourths of total hormonal action. This preeminent role of $\mathrm{T}_{3}$, both in normal and pathological states, would suggest the importance of this hormone in assessing thyroid status in man.

\section{ACKNOWLEDGMENTS}

The study was supported in part by U. S. Public Health Service Research Grant AM 11727 and U. S. Public Health Service Training Grant AM 05176 from the National Institutes of Arthritis and Metabolic Diseases, Grant RR 43 from the General Clinical Research Centers Program of the Division of Research Resources, National Institutes of Health, U. S. Public Health Service Grant HD-04270 from the National Institute of Child Health and Human Development, and General Research Support Grant RR05551. Dr. Jean H. Dussault was supported by a grant from the Medical Research Council of Canada.

The authors wish to express their appreciation to $\mathrm{Mr}$. Dwight W. Warren, Miss Evangeline Wise, and Mr. Robert Lam for technical assistance, Mr. Hojat Rostami for mathematical analysis, and Mrs. Anne Santo for preparation of the manuscript.

\section{REFERENCES}

1. Rall, J. E., J. Robbins, and C. G. Lewallen. 1964. The thyroid. In The Hormones. G. Pincus, K. V. Thimann, and E. B. Astwood, editors. Academic Press Inc., New York. 5: 159.

2. Sterling, K., J. C. Lashof, and E. B. Man. 1954. Disappearance from serum of $\mathrm{I}^{131}$-labeled $\mathrm{L}$-thyroxine and L-triiodothyronine in euthyroid subjects. J. Clin. Invest. 33: 1031.

3. Wiswell, J. G., and V. Coronho. 1962. Disappearance of $I^{131}$-triiodothyronine from the plasma in the presence of fever. J. Clin. Endocrinol. Metab. 22: 657.

4. Zaninovich, A. A., R. Volpe, and C. Ezrin. 1969. Effects of variations of thyroxine-binding globulin capacity on the disappearance of triiodothyronine from the plasma. J. Clin. Endocrinol. Metab. 29: 1601.

5. Woeber, K. A., R. J. Sobel, S. H. Ingbar, and K. Sterling. 1969. The peripheral metabolism of triiodothyronine in normal subjects and in patients with hyperthyroidism. J. Clin. Invest. 49: 643.

6. Surks, M. I., and J. H. Oppenheimer. 1969. Formation of iodoprotein during the peripheral metabolism of 3,5,3'triiodo-L-thyronine- ${ }^{125} \mathrm{I}$ in the euthyroid man and rat. J. Clin. Invest. 48: 685 .

7. Nicoloff, J. T., and D. W. Warren. 1969. The failure of 6-propyl-thiouracil (6-PTU) to inhibit the deiodination of $3^{\prime}$ labeled ${ }^{125} \mathrm{I}$ triiodothyronine $\left({ }^{125} \mathrm{I} \mathrm{T}_{3}\right)$. Program of the American Thyroid Association, Inc., 13-15 November 1969. (Abstr.)

8. Sterling, K., and R. B. Chodos. 1956. Radiothyroxine turnover studies in myxedema thyrotoxicosis, and hypermetabolism without endocrine disease. J. Clin. Invest. 35: 806.

9. Tait, J. F., and S. Burstein. 1964. In vivo studies of steroid dynamics in man. In The Hormones. G. Pincus, K. V. Thimann, and E. B. Astwood, editors. Academic Press Inc., New York. 5: 441. 
10. Ingbar, S. H. 1961. Clinical and physiological observations in a patient with an idiopathic decrease in thyroxine-binding globulin of plasma. J. Clin. Invest. 40: 2053.

11. Chopra, I. J., D. H. Solomon, and G. N. Beall. 1971 Radioimmunoassay for measurement of triiodothyronine in human serum. J. Clin. Invest. 50: 2033.

12. West, C. D., V. J. Chavre, and M. Wolfe. 1966. A simple method for estimating serum thyroxine concentration in thyroid disease and iodine-treated patients. J. Clin. Endocrinol. Metab. 26: 986.

13. Rall, J. E., J. Robbins, D. Becker, and R. W. Rawson. 1953. The metabolism of labeled L-triiodothyronine, Lthyroxine and D-thyroxine. J. Clin. Invest. 32: 596. (Abstr.)

14. Gregerman, R. I., and N. Solomon. 1967. Acceleration of thyroxine and triiodothyronine turnover during bacterial pulmonary infections and fever: implications for the functional state of the thyroid during stress and in senescence. J. Clin. Endocrinol. Metab. 27: 93.

15. Koutras, D. A., M. Berman, J. Sfontouris, G. A. Rigopoulos, A. S. Koukoulommati, and B. Malamos. 1970. Endemic goiter in Greece: thyroid hormone kinetics. J. Clin. Endocrinol. Metab. 30: 479.

16. Fisher, D. A., and T. H. Oddie. 1964. Whole-body counting of ${ }^{131} \mathrm{I}$-labeled triiodothyronine. J. Clin. Endocrinol. Metab. 24: 733.

17. Cavalieri, R. R., M. Steinberg, and G. L. Searle. 1971. Metabolic clearance rate (MCR) on L-triiodothyronine $\left(T_{3}\right)$ in man: single-injection vs. constant-infusion methods. Clin. Res. 19: 370. (Abstr.)

18. Nicoloff, J. T., and J. T. Dowling. 1968. Estimation of thyroxine distribution in man. J. Clin. Invest. 47: 26.

19. Oppenheimer, J. H., H. L. Schwartz, H. C. Shapiro, G. Bernstein, and M. I. Surks. 1970. Differences in primary cellular factors influencing the metabolism and distribution of 3,5,3'-triiodothyronie and L-thyroxine. $J$. Clin. Invest. 49: 1061.

20. Cavalieri, R. R., M. Steinberg, and G. L. Searle. 1970. The distribution of triiodothyronine: studies of euthyroid subjects with decreased plasma thyroxine-binding globulin and patients with Graves' disease. J. Clin. Invest. 49: 1041.

21. Nauman, J. A., A. Nauman, and S. C. Werner. 1967. Total and free triiodothyronine in human serum. J. Clin. Invest. 46: 1346.
22. Hollander, C. S. 1968. On the nature of the circulating thyroid hormone: clinical studies of triiodothyronine and thyroxine in serum using gas chromatographic methods. Trans. Ass. Amer. Physicians Philadelphia. 81: 76.

23. Sterling, K., D. Bellabarba, E. S. Newman, and M. A. Brenner. 1969. Determination of triiodothyronine concentration in human serum. J. Clin. Invest. 48: 1150.

24. Larson, P. R. 1970. Triiodothyronine $\left(T_{3}\right)$ in human serum: determinations based on methodological improvements. Clin. Res. 18: 603. (Abstr.)

25. Gharib, H., W. E. Mayberry, and R. J. Ryan. 1970. Radioimmunoassay for triiodothyronine. J. Clin. Endocrinol. Metab. 31: 709.

26. Benotti, J., R. Grimaldi, S. Pino, and F. Maloof. 1970. A modified method for total triiodothyronine $\left(T_{3}\right)$ by competitive protein binding. Abstract No. 127. Sixth International Thyroid Conference, Vienna, Austria. 139.

27. Wahner, H. W., and C. A. Gorman. 1971. Interpretation of serum triiodothyronine levels measured by the Sterling technic. N. Engl. J. Med. 284: 225.

28. Fisher, D. A., and J. H. Dussault. 1971. Contribution of methodological artifacts to the measurement of $\mathrm{T}_{3}$ concentration in serum. J. Clin. Endocrinol. Metab. 32: 675.

29. Ingbar, S. H., and N. Freinkel. 1958. Studies of thyroid function and the peripheral metabolism of $\mathrm{I}^{131}$-labeled thyroxine in patients with treated Graves' disease. J. Clin. Invest. 37: 1603.

30. Braverman, L. E., A. E. Foster, and S. H. Ingbar. 1968. Thyroid hormone transport in the serum of patients with thyrotoxic Graves' disease before and after treatment. J. Clin. Invest. 47: 1349.

31. Nicoloff, J. T., and J. T. Dowling. 1968. Studies of peripheral thyroxine distribution in thyrotoxicosis and hypothyroidism. J. Clin. Invest. 47: 2000.

32. Schussler, G. C., and V. K. Vance. 1968. Effect of thyroid-suppressive doses of triiodothyronine on thyroxine turnover and on the free thyroxine fraction. J. Clin. Invest. $47: 720$.

33. Farmer, T. A., Jr., T. C. Smitherman, R. J. Beschi, and J. A. Pittman, Jr. 1969. Effect of triiodothyronine administration on serum PBI in hypothyroid patients maintained on constant doses of thyroxine. J. Clin. Endocrinol. Metab. 29: 781.

34. Ingbar, S. H. 1960. Clinical and physiologic implications of thyroxine turnover in man. In Clinical Endocrinology. I. E. B. Astwood, editor. Grune \& Stratton, Inc., New York. 91. 